\title{
A Preliminary Study on the Physicochemical, Microbiological and Sensory Characteristics of Purslane and/or Cayenne Pepper Added Drinking Yogurt, A Traditional Anatolian Beverage
}

\author{
Atiye DEGIRMENCI ${ }^{1}$, Mehtap ER KEMAL ${ }^{2}$, Gülsüm Merve BOYRACI ${ }^{3 *}$, Mehmet KEMAL ${ }^{4}$, \\ Oktay YILDIZ ${ }^{5}$
}

\begin{abstract}
Drinking yogurt (ayran) is one of the valuable traditional Anatolian dairy products. Ayran is prepared traditionally through adding water and salt to yogurt or manufactured industrially by fermentation of yogurt culture added diluted milk. Nowadays, interest and consumption of traditional different fermented dairy products have spread rapidly around the world. Although cucumber-yogurt (cacik), soda ayran, fruitful ayran have a commercial face, there is still locally consumed drinking yogurt ayran types. One of the locally consumed ayran types is herby-hot ayran from Puturge-Malatya. In the preparation of herby-hot ayran, the flavoring herbs/spices are added to the ayran in earthenware pots then buried under the soil and left to ferment spontaneously for at least 15 days. The objectives of this study were to determine physicochemical, microbiological, and sensory properties of traditional purslane and/or Cayenne pepper added drinking yogurt from Puturge-Malatya, Turkey. The analysis results were found total dry matter 5.80-7.03 \%, pH 3.77-4.30, titratable acidity $0.61-1.17 \%$ lactic acid, serum separation $11.17-21.5 \mathrm{~mL}(50 \mathrm{~mL})^{-1}$. Levels of lactic acid bacteria (LAB) ranged from 7.00 to $8.04 \mathrm{log}$ cfu $\mathrm{mL}^{-1}$ and the mold and yeast (MY) levels varied from 5.25 to $6.98 \mathrm{log} \mathrm{cfu} \mathrm{mL}^{-1}$ for studied samples. Properties of traditional herby-hot ayran are found different from plain ayran. The results demonstrated that this product may have the potential for consumer preference. To reveal the changes occurring in product characteristics during the fermentation period would be thus of interest.
\end{abstract}

Keywords: Fermented products, Drinkable yogurt, Herby hot ayran, Purslane, Cayenne pepper

\section{Geleneksel Bir Anadolu İçeceği olan Semizotu ve/veya Acı Biber İlaveli Ayranın Fizikokimyasal, Mikrobiyolojik ve Duyusal Özellikleri Üzerine Bir Ön Çalışma}

\section{$\ddot{O ̈ z}$}

İçilebilir yoğurt (ayran), Anadolu'nun değerli geleneksel süt ürünlerinden biridir. Ayran geleneksel olarak yoğurda su ve tuz ilave edilerek hazırlanır veya yoğurt kültürü ilave edilen seyreltilmiş sütün fermantasyonu ile endüstriyel olarak üretilir. Günümüzde, geleneksel farklı fermente süt ürünlerinin tüketimi ve onlara olan ilgi dünya çapında hızla yayılmaktadır. Cacık, sodalı ayran, meyveli ayran ticari bir yüze sahip olsa da, hala yerel olarak tüketilen ayran çeşitleri mevcut olup bunlardan biri de Puturge-Malatya'nın otlu-acılı ayranıdır. Otlu-acılı ayran üretiminde, çömleklerdeki ayrana aroma verici otlar/baharatlar eklenir ve en az 15 gün toprak altındaki çömleklerde spontan fermantasyona bırakılır. Bu çalışmanın amacı, Puturge-Malatya'nın geleneksel semizotu ve/veya acı biber ilaveli ayranının fizikokimyasal, mikrobiyolojik ve duyusal özelliklerini belirlemektir. Örneklerin toplam kuru madde \% 5.80-7.03, pH 3.77-4.30, titre edilebilir asitlik \% 0.61-1.17 laktik asit ve serum ayrılması $11.17-21.5 \mathrm{~mL}(50 \mathrm{~mL})^{-1}$ aralığında belirlenmiştir. Laktik asit bakteri (LAB) seviyeleri 7.00 ile $8.04 \mathrm{log}$ cfu mL ${ }^{-1}$ ve küf ve maya (MY) değerleri 5.25 ile $6.98 \log \mathrm{cfu} \mathrm{mL}^{-1}$ arasında değişmiştir. Geleneksel otlu-acılı ayranın özellikleri sade ayrandan farklı bulunmuştur. Çalışmanın sonuçları, bu ürünün tüketicilerin tercih edebileceği bir potansiyele sahip olabileceğini göstermiştir. Fermantasyon sırasında ürün karakteristiğinde meydana gelen değişiklikleri ortaya çıkarmak bundan sonraki çalışmamızda ilgi alanımız olacaktır.

Anahtar Kelimeler: Fermente ürünler, İçilebilir yoğurt, Otlu acılı ayran, Semiz otu, Acı biber.

\footnotetext{
${ }^{1,2,3}$ Karadeniz Teknik Üniversitesi, Maçka Meslek Yüksekokulu, Gıda İşleme Bölümü, Trabzon, Türkiye, atiyeyaygaz@ktu.edu.tr mehtaper@ktu.edu.tr merveturkut@ktu.edu.tr

${ }^{4}$ Artvin Çoruh Üniversitesi, Sağlık Bilimleri Fakültesi, Beslenme ve Diyetetik Bölümü, Artvin, Türkiye, mkemal@artvin.edu.tr

${ }^{5}$ Karadeniz Teknik Üniversitesi, Eczacılık Fakültesi, Temel Eczacılık, Trabzon, Türkiye, oktayyildiz@ktu.edu.tr
}

${ }^{1}$ https://orcid.org/0000-0003-4767-2667 ${ }^{4}$ https://orcid.org/0000-0003-2561-807X
${ }^{2}$ https://orcid.org/0000-0003-0347-6648 ${ }^{5}$ https://orcid.org/0000-0003-0436-682X 


\section{Introduction}

Dairy products have been widely consumed since the early history of mankind. Milk-based products especially fermented ones make a considerable contribution to human health depend on rich sources of beneficial metabolic compounds. Nowadays, a wide range of yogurt forms is consumed all over the world. Fermented milk beverages are called drinking yogurt in Europe, kefir and kumis in the Middle East, lassi in India and ayran in Turkey with different names according to cultures (Karim et al., 2017). Ayran, drinkable yogurt, is a fermented dairy product made by the addition of water to yogurt (homemade) or addition of yogurt cultures; Streptococcus thermophilus and Lactobacillus delbrueckii subsp. bulgaricus to industrially produced standardized milk (TPC, 2009). Additively plain ayran, different types of ayran are generally consumed such as cucumber-yogurt (tsatsiki), herby ayran, soda ayran, fruitful ayran. The dairy product marketplace continues to go forward as the popularity of the diet-health relationships is on the rise among consumers. This increase is also due to radical cultural, social and economic changes worldwide.

A certain product variety is currently available for the dairy industry. However, a number of traditional dairy products are still waiting for commercial interest. One of these is Puturge ayran which may meet functional alternatives' demand of consumers. Herby-hot ayran called "Puturge ayran" in Turkish, is mainly consumed in Puturge-Malatya, Turkey. Puturge County is located in the most eastern area of Malatya City, Turkey and is surrounded by the southeastern Taurus Mountains (Tuna et al., 2020). The ingredients of this traditional fermented beverage are yogurt, purslane, Cayenne pepper, water, and salt. By those functional ingredients, a fortified, flavored, healthpromoting form of plain ayran has been conventionally obtained. One of the aims of the present study was to examine the physicochemical, microbiological and sensorial properties of Puturge ayran. The other outstanding point was to compare characteristics of plain ayran with Puturge ayran. There are studies mentioning the physicohemical properties of fruit-added yogurt. Only one other study has analysed powdered and sliced Cayenne pepper addition on the properties of ayrans (Akcay et al., 2020). To the best of our knowledge, this is the first paper to investigate physicohemical and microbiological characteristics of Cayenne pepper and/or purslane added ayran as a traditional Anatolian beverage: Malatya's Puturge ayran.

\section{Material and Methods}

Puturge ayran samples manufactured in August 2017 were supplied from Puturge Food, Agriculture and Livestock District Direction, Malatya, Turkey. Samples were identified and named as A (ayran with purslane and Cayenne pepper), B (ayran with purslane), C (ayran with Cayenne 
pepper), D (plain ayran). Traditional ayran samples were manufactured by mixing of $0.5 \mathrm{~kg}$ yogurt, 3.5 L water, $160 \mathrm{~mL}$ soda, and $50 \mathrm{~g}$ salt. Produced drinking yogurts contain different amounts of purslane and/or Cayenne pepper. The formulation of samples along with details is shown in Table 1. Spontane fermentation in earthenware pots buried under the soil was performed for 15 days. Ayrans were passed through by using classic kitchen utensils to remove solid parts of samples in accordance with the traditional consumption. Drinkable yogurt samples were refrigerated at $+4{ }^{\circ} \mathrm{C}$ for two days until measurements.

Table 1. Formulation of drinking yogurts

\begin{tabular}{lcccccc}
\hline & \multicolumn{5}{c}{ Ingredients } \\
\cline { 2 - 7 } Sample & Yogurt (g) & Water (L) & Salt (g) & Soda $(\mathrm{mL})$ & Cayenne pepper (g) & Purslane $(\mathrm{g})^{*}$ \\
\hline $\mathrm{A}$ & 500 & 3.5 & 50 & 160 & 240 & 400 \\
$\mathrm{~B}$ & 500 & 3.5 & 50 & 160 & - & 400 \\
$\mathrm{C}$ & 500 & 3.5 & 50 & 160 & 240 & - \\
$\mathrm{D}$ & 500 & 3.5 & 50 & - & - & - \\
\hline
\end{tabular}

* Purslane was cutting into small pieces, boiled for 20 minutes and drained.

\subsection{Physicochemical Analysis}

Total dry matter, water-soluble dry matter ( $\left.{ }^{\circ} \mathrm{Brix}\right), \mathrm{pH}, \%$ titratable acidity (lactic acid based) contents of samples were determined according to AOAC (2005) standardized methods. Serum separation analysis was determined based on Koksoy and Kilic (2003). Results were given as mL of serum separation per $50 \mathrm{~mL}$ ayran.

\subsection{Color Analysis}

The color values of the samples were determined using the A Hunterlab Colorflex CFLX 45-2, VA instrument and measured CIE L*, a* and b* values (Estrada et al., 2011).

\subsection{Microbiological Analysis}

$10 \mathrm{ml}$ of sample and $90 \mathrm{ml}$ of sterile $0.85 \% \mathrm{NaCl}$ solution were homogenized for 3 minutes and inoculated into petri dishes from the $10^{-9}$ dilution series. This process was repeated for each ayran sample. Total mesophilic aerobic bacteria (TMAB) were determined using Plate Count Agar (PCAMerck) at $37{ }^{\circ} \mathrm{C}$ for $48 \mathrm{~h}$ and mold-yeast count were determined by incubating in Potato Dextrose Agar (PDA-Merck) at $25^{\circ} \mathrm{C}$ for 3-5 days. Also, Lactobacilli and Lactococci numbers were counted in MRS agar at $44{ }^{\circ} \mathrm{C}$ and in M17 agar at $37{ }^{\circ} \mathrm{C}$ for $48 \mathrm{~h}$, respectively. Additionally, possible 
Escherichia coli and coliform bacteria colony numbers in ayran were defined with Violet Red Bile Agar (Downes and Ito, 2001). Results were indicated as colony-forming units (log cfu) per mL of ayran.

\subsection{Sensory Evalutaion}

Coded samples were kept at room temperature for 10-15 minutes before sensory evaluation and served with water. The sensorial characteristics of studied ayran samples were evaluated by a jury of 12 panelists with 10-point scale according to five parameters: appearance, body-texture, taste-flavor, odor and general acceptance (Altug Onogur and Elmaci, 2011).

\subsection{Statistical Analysis}

Obtained results were shown as means \pm standard deviations, and processed by ANOVA followed by Duncan's test (p-value 0.05) using the software SPSS 20.

\section{Results and Discussion}

The results of physicochemical properties of ayran samples are shown in Table 2. Control ayran differed statistically from other ayran samples. A study on some physicochemical properties of 20 different plain ayran samples were reported that the $\mathrm{pH}$ values range between 3.60-4.70 (Cetin et al., 2014). The $\mathrm{pH}$ range were given as $4.10-4.17$ by Erkaya et al. (2015). Our results for the samples were similar to those in the stated reports. Ayran samples were formulated by different ingredients i.e. purslane and Cayenne pepper that may affect the physicochemical characteristics of samples. The effects of purslane and Cayenne pepper addition on $\mathrm{pH}$ and titratable acidity were found to be significant. However, no significant differences were found between $\mathrm{pH}$, \%titratable acidity, and ${ }^{\circ}$ Brix of Puturge ayran samples. This result was actually expected since the purslane and Cayenne pepper in their content were sieved before the storage stage in accordance with the traditional consumption. Control sample has the highest $\mathrm{pH}(\mathrm{pH}: 4.30)$ and the lowest titratable acidity values. The acidity and the $\mathrm{pH}$ level of a fermented product are associated with the microbial load and activity conditions (Erkaya et al., 2015). This may be because of the bacterial growth and the production of lactic acid in samples. The presence of the prebiotic polysaccharides that might sustain the metabolism of lactic acid bacteria and lactic acid bacteria decrease $\mathrm{pH}$ by producing organic acids. As it is well known that the proteolytic activity of Lactobacilli is higher than that of Lactococci. Cayenne pepper and/or purslane added samples were dominated by Lactobacilli. Therefore, it is 
thought that the increase in Lactobacilli counts improve proteolysis and may contribute to titratable acidity of samples.

Table 2. $\mathrm{pH}$, titratable acidity (\%), total soluble dry matter content $\left({ }^{\circ}\right.$ Brix $)$ of samples

\begin{tabular}{cllll}
\hline Sample & $\mathrm{pH}$ & $\begin{array}{l}\text { Titratable acidity } \\
(\% \text { lactic acid) }\end{array}$ & $\begin{array}{l}\text { Total soluble dry matter } \\
\left({ }^{\circ} \text { Brix }\right)\end{array}$ & $\begin{array}{l}\text { Serum separation } \\
\mathrm{mL}(50 \mathrm{~mL})^{-1}\end{array}$ \\
\hline $\mathrm{A}$ & $3.87 \pm 0.01^{\mathrm{a}}$ & $1.12 \pm 0.01^{\mathrm{a}}$ & $4.10 \pm 0.01^{\mathrm{a}}$ & $21.50 \pm 0.36^{\mathrm{d}}$ \\
$\mathrm{B}$ & $3.77 \pm 0.02^{\mathrm{a}}$ & $1.15 \pm 0.01^{\mathrm{a}}$ & $4.00 \pm 0.01^{\mathrm{a}}$ & $16.17 \pm 0.17^{\mathrm{b}}$ \\
$\mathrm{C}$ & $3.89 \pm 0.01^{\mathrm{a}}$ & $1.17 \pm 0.07^{\mathrm{a}}$ & $4.00 \pm 0.10^{\mathrm{a}}$ & $17.33 \pm 0.19^{\mathrm{c}}$ \\
$\mathrm{D}$ & $4.30 \pm 0.31^{\mathrm{b}}$ & $0.61 \pm 0.03^{\mathrm{b}}$ & $5.00 \pm 0.20^{\mathrm{b}}$ & $11.17 \pm 0.10^{\mathrm{a}}$ \\
\hline
\end{tabular}

* Different superscripts letters (a-d) in the same column represent significant differences between means $(\mathrm{p}<0.05)$.

Serum separation in acidic fermented dairy products is the formation of the serum phase at the top of the product, which is due to the loss of water from a continuous protein matrix (Gursoy et al., 2016). It is one of the main textural defects in fermented milk drinks (Shirkhani et al., 2015). Serum separation occurs due to sedimentation of large particles and casein proteins at the bottom due to aggregation (Kiani et al., 2008). Fermentation temperature and final $\mathrm{pH}$ are important factors influencing serum separation as they would affect the structure of the protein network (Ozdemir and Kilic, 2004). Low dry matter content, high incubation temperature, rapid acidification, low acid production, and storage conditions have a profound impact on serum separation. The serum separation is unavoidable for traditionally produced ayran because of the lack of homogenization and standardization process. The serum separation results of the analyzed ayran samples were statistically different $(\mathrm{P}<0.05)$. Obtained results are in complete accordance with the values of 21.5, 16.17, 17.33, and $11.17 \mathrm{~mL}(50 \mathrm{~mL})^{-1}$ serum separation for A, B, C, and D samples, respectively (Table 2). The water holding capacity of protein molecules is limited under low acidity conditions. Since the highest $\mathrm{pH}$ and the lowest serum separation values belong to the plain ayran, it can be said that the acidity does not cause this type of change. It seems that, in this case, serum separation may be associated with total soluble solid content of samples. The total soluble solid content in plain ayran was higher than that in purslane and/or Cayenne pepper added samples. The use of total soluble solids by higher number of bacteria for their metabolism in purslane and/or Cayenne pepper added samples may cause lower soluble solid content and higher serum separation phenomenon. Many studies have been performed considering stabilizing agents (Laurent and Boulenguer, 2003; Janhoj et al., 2008; Anli et al., 2013; Gharibzahedi and Chronakis, 2018), emerging technologies such as ultrasound (Ertugay et al., 2012) and thermosonication (Riener et al., 2009) to prevent serum separation for fermented dairy products. 
The color parameters $\mathrm{L}^{*}, \mathrm{a}^{*}$, and $\mathrm{b}^{*}$ of all studied ayran samples (Table 3) presented significant differences $(\mathrm{P}<0.05)$. Samples formulated with the purslane $(\mathrm{B})$, purslane and Cayenne pepper $(\mathrm{A})$ had darker color values (lower $\mathrm{L}^{*}$ and higher $\mathrm{a}^{*}$ ) compared with plain ayran. The decrease in luminosity was increased with the addition of the Cayenne pepper and purslane. Those values may be attributed to the leakage of natural pigments to the drinking yogurt samples. The purslane and Cayenne pepper added sample made higher contribution of the red color than purslane added ayran. However, the same changes were not detected in Cayenne pepper added samples. The anthocyanins can be easily degradable and affected by the microbial flora and $\mathrm{pH}$, and can exhibit colourless or brown-coloured compounds (Karaaslan et al., 2011). From this point of view, it is thought that the differences in the color values of the Cayenne pepper added samples (C) are not only due to the formulations, but also to the complex reactions including anthocyanin degradation and microbial activity.

Table 3. Color values of samples

\begin{tabular}{cccc}
\hline Sample & $\mathrm{L}^{*}$ & $\mathrm{a}^{*}$ & $\mathrm{~b}^{*}$ \\
\hline A & $4.81 \pm 0.23^{\mathrm{a}}$ & $7.08 \pm 0.38^{\mathrm{d}}$ & $7.99 \pm 0.23^{\mathrm{a}}$ \\
$\mathrm{B}$ & $7.00 \pm 0.07^{\mathrm{b}}$ & $5.97 \pm 0.10^{\mathrm{c}}$ & $11.60 \pm 0.14^{\mathrm{b}}$ \\
C & $16.74 \pm 0.23^{\mathrm{d}}$ & $0.08 \pm 0.03^{\mathrm{a}}$ & $24.01 \pm 0.40^{\mathrm{d}}$ \\
D & $10.45 \pm 0.14^{\mathrm{c}}$ & $0.56 \pm 0.04^{\mathrm{b}}$ & $16.76 \pm 0.18^{\mathrm{c}}$ \\
\hline
\end{tabular}

* Different superscripts letters (a-d) in the same column represent significant differences between means $(\mathrm{p}<0.05)$.

Table 4. Sensory evaluation results for ayran samples

\begin{tabular}{lllll}
\hline Sample & Appearance & Texture & Taste & Odor \\
\hline A & & & \\
B & $7.05 \pm 0.76^{\mathrm{a}}$ & $8.76 \pm 1.17^{\mathrm{b}}$ & $7.20 \pm 1.59^{\mathrm{ab}}$ & $8.44 \pm 0.38^{\mathrm{bc}}$ \\
C & $7.05 \pm 1.18^{\mathrm{a}}$ & $8.36 \pm 1.07^{\mathrm{ab}}$ & $7.61 \pm 0.54^{\mathrm{ab}}$ & $7.78 \pm 1.41^{\mathrm{b}}$ \\
D & $9.80 \pm 0.27^{\mathrm{b}}$ & $7.36 \pm 0.82^{\mathrm{a}}$ & $6.19 \pm 1.43^{\mathrm{a}}$ & $6.54 \pm 0.43^{\mathrm{a}}$ \\
\hline
\end{tabular}

*Different superscripts letters $(\mathrm{a}-\mathrm{c})$ in the same column represent significant differences between means $(p<0.05)$.

Plain ayran had the highest score, while the others did not show a significant difference for in the case of appearance (Table 4). The darkening effect of purslane and Cayenne pepper in formulation did not reflect the appearance scores of Puturge ayrans. Texture descriptors were used as homogeneity, smoothness, and thickness Ayran with Cayenne pepper $(\mathrm{C})$ were rated lower $(\mathrm{P}<0.05)$ than the others in terms of texture. Although the color measurement results do not completely overlap with the appearance scores, the low texture score of the sample with Cayenne pepper (C) indicates that there is a problem in terms of homogeneity and smoothness in the sample. This problem may be the other reason for the difference in $\mathrm{L}^{*}, \mathrm{a}^{*}$, and $\mathrm{b}$ values of Cayenne pepper added samples. There is no statistical difference between texture scores of A (ayran with purslane and Cayenne pepper) and 
D (plain ayran). Taste values of samples containing purslane were found similar according to statistical analysis. Plain ayran received the highest score while other ayran types received different scores by panelists when the general acceptability was evaluated (Figure 1).

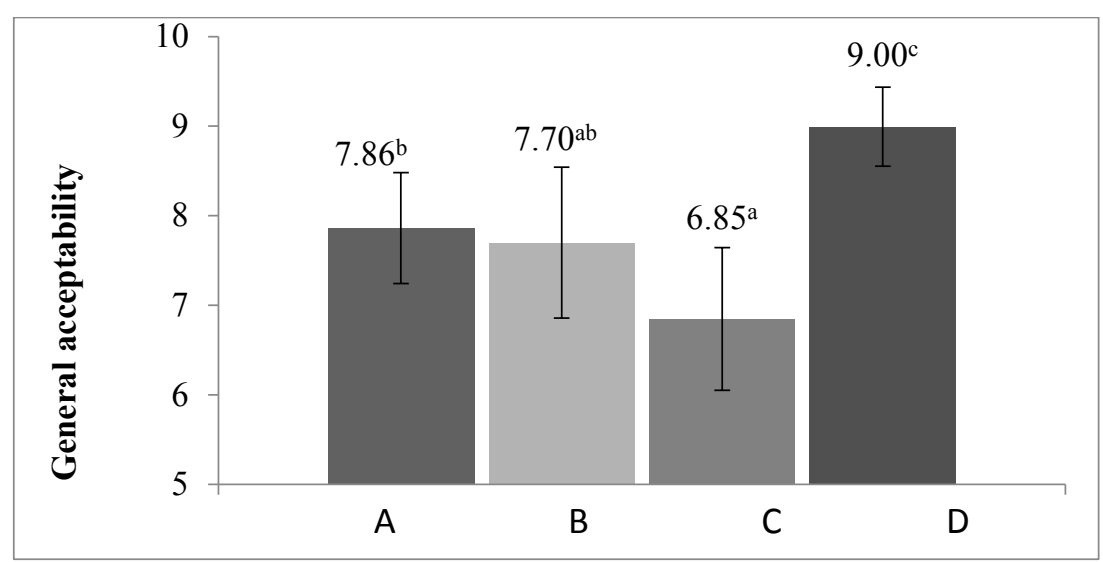

Figure 1. General acceptability results of ayran samples (Values with different superscripts letters on the bars indicate significant differences $(\mathrm{p}<0.05))$.

Quality characteristics including flavor and textural properties are also directly associated with the microbial load. The content of viable microflora and its development is determining factor for the quality and shelf life of dairy products. Types of microorganisms may be increased either by contamination or by the growth of the microorganisms already present (Cardak and Y1lmaz, 2011). Lactic acid bacteria are the most common group of microorganisms in those products. LAB fabricates lactic acid using lactose and can grow at extremely high acid concentrations (Kucukoner et al., 2006). Levels of LAB ranged from 7.00 to $8.04 \mathrm{log} \mathrm{cfu} \mathrm{mL}^{-1}$ for studied samples (Table 5). Significant differences were found between microbial analysis results of herby ayrans and control sample. The LAB counts in herby ayrans were significantly higher than for plain ayran $(\mathrm{P}<0.05)$. There are studies that specifically addressed the plants as a rich source of functional nutrients and prebiotic substances (Joung et al., 2016). Since those substances enhanced the metabolic activities and counts of yogurt bacteria, the $\mathrm{pH}$ was decreased by the production of organic acids in fermentation process (Amirdivani and Baba, 2011). Thus, this result may be evaluated as an evidence of the positive effect of purslane and/or Cayenne pepper towards the counts of traditional yogurt microflora. As it was also expected, traditional drinking yogurts have a higher microbial load than plain ayran. The mold and yeast (MY) levels in the samples were high and varied from 5.25 to $6.98 \log \mathrm{cfu} \mathrm{mL}^{-1}$. E. coli and coliform bacteria were detected in any of the four drinking yogurt. Same maximum range of microbiological values for plain ayran collected from Aydin, Turkey were reported by Cardak and Yilmaz (2011). Kucukoner et al. (2006) found lower values for LAB, TMAB, and yeast and mold in herby cacik. Those authors have also reported that the higher numbers of the mold and yeast may originate from the added herbs. This statement can be accepted for plain ayran (D) and purslane and 
Cayenne pepper added samples (A). However, it was found that plain ayran (D) have the higher mold and yeast loads than ayran with purslane (B) and Cayenne pepper (C). Therefore, there is need for the detailed knowledge on the competition and adaptation of LAB, yeast and molds in Puturge ayran fermentation.

Table 5. Lactic acid bacterial counts, total mesophilic aerobic bacterial counts and mold and yeast counts of ayran samples

\begin{tabular}{ccccc}
\hline \multirow{2}{*}{ Sample } & \multicolumn{4}{c}{ Microbial counts $\left(\right.$ Log cfu $\left.\mathrm{mL}^{-1}\right)$} \\
\cline { 2 - 5 } & Lactobacilli & Lactococci & TMAB & MY \\
\hline A & $7.70 \pm 0.14^{\mathrm{b}}$ & $7.55 \pm 0.21^{\mathrm{b}}$ & $8.39 \pm 0.14^{\mathrm{bc}}$ & $6.98 \pm 0.19^{\mathrm{c}}$ \\
B & $8.04 \pm 0.28^{\mathrm{b}}$ & $8.00 \pm 0.04^{\mathrm{c}}$ & $8.10 \pm 0.29^{\mathrm{ab}}$ & $5.28 \pm 0.22^{\mathrm{a}}$ \\
C & $8.03 \pm 0.36^{\mathrm{b}}$ & $7.94 \pm 0.17^{\mathrm{c}}$ & $8.58 \pm 0.14^{\mathrm{c}}$ & $5.25 \pm 0.04^{\mathrm{a}}$ \\
D & $7.00 \pm 0.02^{\mathrm{a}}$ & $7.38 \pm 0.08^{\mathrm{a}}$ & $8.00 \pm 0.05^{\mathrm{a}}$ & $6.00 \pm 0.02^{\mathrm{b}}$ \\
\hline
\end{tabular}

* Different superscripts letters $(\mathrm{a}-\mathrm{c})$ in the same column represent significant differences between means $(\mathrm{p}<0.05)$.

\section{Conclusion}

Lately, food products at remained regional level are well-perceived and demanded. One of the traditional products, Puturge ayran, was researched in terms of some physicochemical, microbiological and sensory characteristics. The results are demonstrated that Puturge ayran has potential in terms of consumer attitude. It is thought that rheological characteristics and shelf life of this product should also be studied. Detailed investigations, further studies and advertising are vital for awakening food producers' interest and providing added value to Malatya's Puturge ayran. To reveal the changes occurring in product characteristics during the fermentation period would be thus of interest.

\section{Acknowledgments}

The authors would like to give special thanks to the Puturge Food, Agriculture and Livestock District Direction, Malatya, Turkey who assisted with the production of samples. Some part of this article was presented as a poster presentation in International Symposium on Medicinal, Aromatic and Dye Plants, Malatya.

\section{Contribution of the Authors}

The 1st, 2 nd and 3 rd authors contributed $75 \%$ equal in total and the 4 th author $10 \%$ and the 5 th author $15 \%$ contributed. 


\section{Disclosure Statement}

No potential conflict of interest was reported by the authors

\section{Research and Publication Ethics Statement}

Research and publication ethics were followed in the study.

\section{References}

Akcay F., Besir A., Yazici F. (2020). Effect of Cayenne Pepper Addition On Physicochemical, Microbiological and Sensory Properties of Drinkable Yoghurt-Ayran. Acta Universitatis Cinbinesis, Series E: Food Technology, 24(1), pp. 79-87.

Altug T., Elmacı, Y. (2011). G1dalarda Duyusal Değerlendirme, Sidas Medya, İzmir, Türkiye.

Amirdivani, S., Baba, A. S. (2011). Changes in yogurt fermentation characteristics, and antioxidant potential and in vitro inhibition of angiotensin-1 converting enzyme upon the inclusion of peppermint, dill and basil. LWT-Food Science and Technology, 44(6), pp. 1458-1464.

Anli T., Sezgin E., Enel E., Benli M. (2013). The effect of transglutaminase on some physicochemical and sensory properties of the Turkish drinking yogurt Ayran. International Journal of Dairy Technology, 66, pp. 410-416.

AOAC. (2005). Official methods of analysis of the association of official analytical chemists (18th ed.), Arlington, VA, The Association.

Çardak A.D., Yilmaz M. (2011). Survey of the bacteriological quality of dairy products in the province of Aydin, Turkey. Milchwissenschaft-Milk Science International, 66(3), pp. 304-306.

Cetin B., Atik A., Karasu S. (2014). Kırklareli’nde Üretilen Yoğurt ve Ayranların Fizikokimyasal ve Mikrobiyolojik Kalitesi. Academic Food Journal/Akademik GIDA, 12(2), pp. 57-60.

Downes, F. P., Ito, K. (2001). Compendium of methods for the microbiological examination of foods, American Public Health Association, Washington, USA.

Erkaya T., Başlar M., Şengül M., Ertugay M.F. (2015). Effect of thermosonication on physicochemical, microbiological and sensorial characteristics of ayran during storage. Ultrasonics sonochemistry, 23, pp. 406-412.

Ertugay M.F., Baslar M., Sengul M., Sallan S. (2012). The effect of acoustic energy on viscosity and serum separation of traditional Ayran, a Turkish Yogurt Drink. Gida, 37, pp. 253-257.

Estrada, J. D., Boeneke, C., Bechtel, P., Sathivel, S. (2011). Developing a strawberry yogurt fortified with marine fish oil. Journal of Dairy Science, 94(12), pp. 5760-5769.

Gharibzahedi S.M.T., Chronakis I.S. (2018). Crosslinking of milk proteins by microbial transglutaminase: utilization in functional yogurt products. Food chemistry, 245, pp. 620-632.

Gursoy O., Yilmaz Y., Gokce O., Ertan K. (2016). Effect of ultrasound power on physicochemical and rheological properties of yogurt drink produced with thermosonicated milk. Emirates Journal of Food and Agriculture, 28(4), pp. 235-241.

Janhoj T., Frost M.B., Ipsen R. (2008). Sensory and rheological characterization of acidified milk drinks. Food Hydrocolloids, 22 (5): 798-806.

Joung, J. Y., Lee, J. Y., Ha, Y. S., Shin, Y. K., Kim, Y., Kim, S. H., Oh, N. S. (2016). Enhanced microbial, functional and sensory properties of herbal yogurt fermented with Korean traditional plant extracts. Korean journal for food science of animal resources, 36(1), pp. 90-99.

Karaaslan, M., Ozden, M., Vardin, H., Turkoglu, H. (2011). Phenolic fortification of yogurt using grape and callus extracts. LWT-Food Science and Technology, 44(4), pp. 1065-1072.

Karim M., Alimi M., Shokoohi S., Fazeli F. (2017). Effect of long-chain inulin and modified starch on the physicochemical and rheological properties of doogh (Iranian yogurt drink). Acta Alimentaria, 46(1), pp. 51-60. 
Kiani H., Mousavi S.M.A., Emam-Djomeh Z. (2008). Rheological properties of Iranian yogurt drink. Doogh, International Journal of Dairy Science, 3(2), pp. 71-78.

Köksoy A., Kılıç M. (2003). Effects of water and salt level on rheological properties of ayran, a Turkish yogurt drink. International Dairy Journal, 13(10), pp. 835-839.

Kucukoner E., Tarakci Z., Sagdic O. (2006). Physicochemical and microbiological characteristics and mineral content of herby cacik, a traditional Turkish dairy product. Journal of the Science of Food and Agriculture, 86(2), pp. 333-338.

Laurent M.A., Boulenguer P. (2003. Stabilization mechanism of acid dairy drinks (ADD) induced by pectin. Food Hydrocolloids, 17(4), pp. 445-454.

Ozdemir U., Kilic M. (2004). Influence of fermentation conditions on rheological properties and serum separation of ayran. Journal of texture studies, 35(4), pp. 415-428.

Riener J., Noci F., Cronin D.A., Morgan D.J., Lyng J.G. (2009). The effect of thermosonication of milk on selected physicochemical and microstructural properties of yogurt gels during fermentation. Food Chemistry, 114(3), pp. 905-911.

Shirkhani M., Madadlou A., Khosrowshahi A. (2015). Enzymatic modification to stabilize the fermented milk drink. Doogh, Journal of Texture Studies, 46(1), pp. 22-33.

TFC. (2009). Turkish Food Codex, fermented milk products. Turkish Food Codex Regulations, Regulation No: 2009/25. Republic of Turkey Ministry of Food, Agriculture and Livestock, Ankara, Turkey.

Tuna A., Ay B.H., Karakuş Ş. (2020). Integration of medicinal and aromatic plants in an urban landscape as a living heritage: an example in Malatya City (Turkey). Environmental Monitoring and Assessment, 192(8), pp. 1-16. 